\title{
Satisfactory screening for cystic fibrosis with the BM meconium procedure
}

\author{
RT EVANS, * AJ LitTle, * AE STEEL, $\dagger$ JM LitTleWOOD \\ From the *Departments of Clinical Biochemistry and $¥$ Paediatrics, St James’s University Hospital, Leeds, \\ and the $\dagger$ Department of Clinical Biochemistry, Seacroft Hospital, Leeds
}

SUMmaRY The Boehringer Mannheim test (BM test) for cystic fibrosis has been applied to 15734 neonates. A positive result occurred in 130, seven of whom were subsequently shown to have the disease. To our knowledge no cases have been missed. Tests have been performed centrally by experienced laboratory staff and the false-positive rate of $0.83 \%$ is considered acceptable. It is important to follow up weak as well as strongly positive reactions to the BM test strip.

Cystic fibrosis (CF) is a serious inherited disorder affecting one infant in 2000 in this country. It is characterised by repeated chest infections, malabsorption secondary to pancreatic insufficiency and a raised salt content in the sweat. At the present time, the state of progression of the lung damage is a major factor in determining prognosis, although nutritional problems are becoming increasingly important as prolonged survival becomes more common.

There is now considerable evidence for improved duration and quality of life among children in whom the diagnosis has been made early, before progressive lung disease is advanced and the general condition compromised by nutritional deficiencies. ${ }^{1}$ Furthermore, comparisons of the fate of second siblings in whom the diagnosis has been made at birth, with the first sibling in the family, supports the advantages of early diagnosis. ${ }^{2}$ While potentially this could be effected by means of a neonatal screening programme, no method has so far been available which is free from unacceptably large numbers of both falsepositive and -negative reactions.

One possible screening test for $\mathrm{CF}$ has been advocated based upon the presence of increased amounts of protein in meconium from affected infants. $^{34}$ Since 1975 a commercially available purpose-made strip test-the BM meconium test combination (BM test)-has been widely used for this purpose. Authors have expressed different views as to the reliability of the test, ${ }^{5-7}$ but most agree that for $10 \%$ of $\mathrm{CF}$ infants with near normal or normal pancreatic function, a false-negative meconium test is likely. Such patients have been well documented. ${ }^{8}$

Accepted for publication 2 February 1981
Our report describes the successful use of the BM test for screening 15734 neonates over 4 years 3 months in a well-defined neonatal population.

\section{Material and methods}

Meconium specimens passed within the first $24 \mathrm{~h}$ were tested in the chemical pathology laboratory with the BM meconium test combination (Boehringer Corporation, Mannheim, GFR). Specimens were stored at $4^{\circ} \mathrm{C}$ if there was likelihood of delay before analysis. Any evidence at all of a blue coloration of the test strip was regarded as positive and an indication for further investigation.

All infants who had a positive BM meconium test had a sweat test within the first month of life and, whenever possible, a second six months later. Sweat electrolytes were measured following pilocarpine iontophoresis $^{9}$ by senior laboratory staff widely experienced in the technique. Adequate sweat collections were not always achieved during the first week of life but use of the small of the back as the collection site invariably resulted in a successful outcome by the age of three weeks.

Occult blood tests were performed by the method of Crossley. ${ }^{10}$

The chymotryptic activity of meconium and faeces has been measured by monitoring the rate of hydrolysis of acetyl tyrosine ethyl ester at $\mathrm{pH} 7.8$ in the presence of calcium and sodium chlorides as activators. ${ }^{11}$ Values found in normal infants lay within the range $80-1000 \mu \mathrm{g} / \mathrm{g}$ wet stool, the distribution of activities being non-gaussian.

The relative concentrations of albumin and $\alpha_{1}$ antitrypsin, the albumin: $\alpha_{1}$ antitrypsin ratio, in homogenates of meconium were measured by radial 911 
immunodiffusion. ${ }^{7}$ A value of up to $2 \cdot 0$ is considered normal. This investigation was introduced late into the screening programme.

The detection of lactase activity in meconium has been based upon the qualitative demonstration of glucose following incubation of meconium with lactose. ${ }^{12}$ No activity is normally expected.

\section{Results}

Between October 1975 and 1 January 1980, 15734 babies were screened. A positive BM test was found in 130 infants, seven of whom were diagnosed for CF. No BM test was performed on an eighth infant who died at the age of two days with meconium ileus. At necropsy the histological findings in pancreas, liver, and salivary glands were typical of CF.

Of the remaining 123 infants, 105 were subsequently shown not to have $C F$ on the basis of normal progress, normal faecal chymotrypsin and sweat tests. Two sweat tests were performed on each of 75 infants while 30 had only a single test. Of 18 infants incompletely evaluated, nine died soon after birth.

Eight false-positive results were associated with the presence of blood in the meconium (usually visible on inspection) and 19 with the presence of meconium "plug" material.

Lactase activity was demonstrated in no less than 29 of 79 specimens from infants who eventually proved to be normal.

\section{Discussion}

Of the seven CF infants detected in this series, three could have been identified as siblings of known patients or because of meconium ileus. However, in the remaining four there was no reason to suspect the diagnosis. As a direct result of the screening programme, prompt treatment and genetic advice were given.
The detection rate is in keeping with the known frequency of the disease..$^{13}$ Extensive enquiries to all the paediatricians in our region have, so far, failed to reveal any evidence of a missed patient from among the infants screened, but, since pancreatic function is alleged to be near normal in $10 \%$ of CF children, it is possible that this proportion will be missed by tests such as this which are based on meconium abnormalities. Other authors have reported a falsenegative rate of up to $25 \%,{ }^{7}$ but we believe that many of these poor results are due to the test being performed on wards by large numbers of inexperienced and uninvolved staff. We would emphasise the need for tests to be carried out centrally and by experienced laboratory workers.

We also regard as essential the full investigation of infants who give a weak-positive BM test. The acceptance of the manufacturer's definition that only a strong blue is indicative of a positive reaction would have resulted in our missing one of the present CF cases.

The test has been criticised because of an unacceptably high false-positive rate. ${ }^{7}$ In our hands, however, the frequency of false-positives was only $0.83 \%$. We consider this acceptable although it necessitates evaluation of a significant number of unaffected infants and the parental anxiety engendered is a continuing problem. Up to the present time sweat tests and faecal chymotrypsin estimations combined with clinical assessment have allowed a reliable diagnosis to be established within a few weeks. The faecal chymotrypsin values have been particularly helpful (Table).

It is possible that in the future immunoreactive trypsin estimations on babies who have a positive BM test will allow an even more rapid evaluation. ${ }^{14} 15$

We anticipate the false-negative rate of this screening programme to approach $10 \%$ with a false-positive rate of $0.8 \%$. We believe that early diagnosis is important and that in the absence of a screening programme, diagnosis may be delayed

\section{Findings in affected infants}

\begin{tabular}{|c|c|c|c|c|c|c|c|}
\hline \multirow[t]{2}{*}{ Infant } & \multirow[t]{2}{*}{ BM test } & \multirow[t]{2}{*}{ Occult blood } & \multirow[t]{2}{*}{ Lactase } & \multirow[t]{2}{*}{ Albumin: $a_{1}$ antitrypsin ratio } & \multirow[t]{2}{*}{ Faecal chymotrypsin $(\mu g / g)$} & \multicolumn{2}{|c|}{ Sweat tests } \\
\hline & & & & & & $\begin{array}{l}\text { Sodium } \\
(\mathrm{mmol} / \mathrm{l})\end{array}$ & $\begin{array}{l}\text { Chloride } \\
\text { (mmol/l) }\end{array}$ \\
\hline 1 & + & - & + & & 10,12 & 175 & 170 \\
\hline 2 & + & - & + & & 33 & $\begin{array}{r}134 \\
89\end{array}$ & $\begin{array}{r}123 \\
120\end{array}$ \\
\hline 3 & Weak + & - & - & & 20,50 & 100 & 109 \\
\hline 4 & + & - & - & & 12 & $\begin{array}{l}114 \\
131\end{array}$ & $\begin{array}{l}150 \\
134\end{array}$ \\
\hline 5 & + & - & - & & 5,10 & $\begin{array}{l}134 \\
110\end{array}$ & $\begin{array}{r}90 \\
140\end{array}$ \\
\hline 6 & + & - & + & 10.8 & $14,19,12$ & $\begin{array}{r}164 \\
88\end{array}$ & $\begin{array}{r}180 \\
97\end{array}$ \\
\hline $\begin{array}{l}7 \\
\text { Normal }\end{array}$ & $\begin{array}{l}+ \\
-\end{array}$ & - & + & $\begin{array}{l}3 \cdot 2 \\
<2\end{array}$ & $\begin{array}{l}21,5,4,5 \\
>80\end{array}$ & $\begin{array}{r}135 \\
<60\end{array}$ & $\begin{array}{r}166 \\
<60\end{array}$ \\
\hline
\end{tabular}


until infants have already had a number of chest infections and become severely compromised nutritionally. Early detection reduces parental anxiety and unhappiness during the prediagnosis phase and allows genetic advice to be given before they embark upon a further pregnancy. Until such time as a reliable, cheap alternative test is available we will continue to screen our infants with the BM test taking the precautions to perform the test in the laboratory and to evaluate even weak-positive reactions.

\section{References}

${ }^{1}$ Shwachman H, Redmond A, Khaw KT. Studies in cystic fibrosis. Report of 130 patients diagnosed under 3 months of age over a 20 year period. Pediatrics $1970 ; 46: 335-43$.

2 Orenstein DM, Boot TF, Stern RC, et al. The effect of early diagnosis and treatment in cystic fibrosis. Am J Dis Child 1977;131:973-5.

${ }^{3}$ Green MN, Shwachman H. Presumptive tests for cystic fibrosis based on serum protein in meconium. Pediatrics $1968 ; 41$ :989-92.

${ }^{4}$ Schutt WH, Isles TE. Protein in meconium from meconium ileus. Arch Dis Child 1968;43:178-81.

${ }^{5}$ Prosser R, Owen H, Bull F, et al. Screening for cystic fibrosis by examination of meconium. Arch Dis Child 1974;49:597-601.

'Stephan U, Busch EW, Mollberg H, Hellsing K. Cystic fibrosis detected by means of a test strip. Pediatrics
1975;55:35-8.

${ }^{7}$ Ryley HC, Neale Lynne M, Brogan TD, Bray PT, Screening for cystic fibrosis in the newborn by meconium analysis. Arch Dis Child 1979;54:92-7.

${ }^{8}$ Ryley HC, Bray PT. Screening for cystic fibrosis by analysis of meconium. Clin Chim Acta 1975;64:117-25.

${ }^{9}$ Gibson LE, Cooke RE. A test for concentration of electrolytes in sweat in cystic fibrosis of the pancreas utilizing pilocarpine by iontophoresis. Pediatrics 1959; 23:545-9.

${ }^{10}$ Crossley G. A rapid occult blood test using amidopyrine as oxygen acceptor. J Med Lab Technol 1970;27:340-3.

11 Robinson PG, Elliot RB. Cystic fibrosis screening in the newborn. Arch Dis Child 1976;51:301-4.

12 Antonowicz I, Ishida S, Shwachman H. Studies in meconium: Disaccharidase activities in meconium from cystic fibrosis patients and controls. Pediatrics 1975;56:782-7.

13 di Sant'Agnese PA, Davis Pamela B. Cystic fibrosis in adults. Am J Med 1979;66:121-32.

${ }^{14}$ Crossley Jeanette R, Elliot RB, Smith Patricia A. Dried blood spot screening for cystic fibrosis in the newborn. Lancet 1979;i:472-4.

${ }^{15}$ King DN, Healey AF, Walsh MP, Kuzemko JA. Sensitive trypsin assay for dried blood specimen as a screening procedure for early detection of cystic fibrosis. Lancet $1979 ; \mathrm{ii}: 1217-8$.

Requests for reprints to: Dr RT Evans, St James's, University Hospital, Beckett Street, Leeds LS9 7TF, England. 